\title{
PENINGKATAN LITERASI DIGITAL PENGRAJIN REYOG PONOROGO MELALUI SISTEM DIGITAL MARKETING
}

\author{
Heri Wijayanto', Alip Sugianto ${ }^{2}$, Rhesma Intan Vidyastari ${ }^{3}$ \\ ${ }^{1}$ Fakultas Ekonomi Universitas Muhammadiyah Ponorogo \\ ${ }^{2}$ Fakultas Ekonomi Universitas Muhammadiyah Ponorogo \\ ${ }^{3}$ Fakultas Teknik Universitas Muhammadiyah Ponorogo
}

Email: ok_coi@yahoo.com, sugiantoalip@gmail.com, rhesma.inta@gmail.com

\begin{abstract}
Abstrak
Teknologi informasi sebagai pilar pembangunan nasional, sebagaimana visi teknologi informasi Indonesia yaitu terwujudnya Indonesia sebagai negara tangguh dalam kompetisi global, melalui pengembangan dan pemanfaatan teknologi informasi dan komunikasi demi terbentuknya masyarakat sejahtera berbasis pengetahuan yang berpegang teguh pada nilai-nilai luhur bangsa. Ketidakmampuan menyesuaikan diri dengan kecenderungan global akan membawa masyarakat pada keterisolasian dari perkembangan global karena tidak mampu memanfaatkan informasi. Kondisi inilah yang terjadi di pengrajin perangkat Reyog Ponorogo, sehingga perlu penguatan literasi digital. Program Pengabdian Masyarakat ini bertujuan untuk mendesain system digital marketing perangkat Reyog Ponorogo, sebagai upaya penguatan pemasaran dan mempertahankan nilai budaya adiluhung. Metode yang digunakan dengan konsep perancangan system yang dimulai dengan desain flowchart, data flow diagram, pemrogram, dan desiminasi teknologi. Hasil dari kegiatan pengabdian berupa desain system digital marketing (start up) dengan alamat website: https://ukmreyog.solusi17.com, dan kegiatan desiminasi hasil perancangan system digital marketing kepada pengrajin Reyog Ponorogo dengan capaian dapat meningkatkan literasi digital pengrajin Reyog Ponorogo sebesar 85\%, ditandai dengan keberhasilan pengrajin Reyog Ponorogo dalam memasarkan, mempromomosikan, dan menjual produk melalui system digital marketing.
\end{abstract}

Kata kunci: literasi, digital, Reyog, Ponorogo

\section{PENDAHULUAN}

Kearifan local kabupaten Ponorogo yang paling terkenal adalah kesenian Reyog Ponorogo, perangkat kesenian Reyog Ponorogo terdiri dari Caplokan (kepala Harimau), Dhadak Merak, Topeng Kelonosewandono, Topeng Ganongan, Kepang Kuda (Jaranan), Kenong, Kempul,
Kendang, Angklung, Gong, Terompet, dan beberapa asesories pakaian pentas. Perangkat Reyog Ponorogo tersebut di produksi oleh 35 UMKM yang tersebar di daerah Ponorogo. UMKM di bidang kerajinan perangkat Reyog Ponorogo dibantu oleh pengrajin yang rata-rata berusia 47 tahun 
(Wijayanto dan Kurnianto 2017), dengan pendidikan tidak tamat sekolah, SD dan SMP.

Pemasaran hasil kerajinan Reyog Ponorogo bukan sekedar berorientasi pada profit, namun nilainilai adiluhung harus tetap terjaga, dan dipertahankan sebagai identitas bangsa. Popularitas tanpa dibarengi dengan promosi, publikasi, pencitraan dan pelestarian lambat laun akan pudar bahkan bisa hilang, demikian halnya Reyog Ponorogo yang sudah go international mulai pudar popularitasnya, kasus klaim tari Barongan oleh negara lain adalah bukti bahwa popularitas reyog Ponorogo mulai pudar dengan tersaingi tari Barongan (Wijayanto, 2017).

Literasi digital suatu bangsa dikatakan baik, apabila teknologi informasi dan komunikasi diperkenalkan, hampir tidak ada hambatan yang berarti dalam menerapkan dan mengembangkannya (Djokopranoto \& Indrajid, 2010). Ketidakmampuan menyesuaikan diri dengan kecenderungan global akan membawa bangsa pada kondisi digital divide, yaitu keterisolasian dari perkembangan global karena tidak mampu memanfaatkan informasi (Instruksi Presiden RI, 2003). Kondisi inilah yang terjadi di UMKM pengrajin dan pemangku kepentingan kebudayaan Reyog Ponorogo, sehingga perlu penguatan literasi digital pada semua komponen.

Pandemi Covid-19 memaksa kita untuk meminimalisir kontak fisik secara langsung, oleh karena itu literasi digital perlu ditingkatkan, UKM kerajian Reyog Ponorogo terdampak secara langsung dengan adanya wabah Corona. Reyog Ponorogo Reyog Ponorogo merupakan aset bangsa yang penuh dengan nilai-nilai luhur dan adi luhung, namun dengan adanya pergeseran kepentingan, perubahan esensi, perubahan simbol, perubahan corak dan makna terus terjadi, memungkinkan hilangnya keaslian kesenian. Pakem (suatu ketetapan atau aturan yang sudah ada sejak dahulu kala) Reyog Ponorogo harus dipertahan.

Pergeseran pakem pernah terjadi, di antaranya: tulisan Reog asalnya dari Reyog, yang hurufhurufnya mewakili sebuah huruf depan kata-kata dalam tembang Mocopat Pocung yang berbunyi: Roso kidung/Engwang sukma adiluhung/Yang
Widhi/Olah kridaning Gusti/Gelar gulung kersaning Kang Maha Kuasa. Penggantian nama Reog diterjemahkan kedalam $\boldsymbol{R}$ esik iku agawe kasarasan, $\boldsymbol{E}$ ndah katon rapi sinawang edipeni, Omber tinarbuka sepi ing pamrih rame ing gawe, Girang gumirang ngudi ayem tentrem lan raharja (Zamzam Fauzannafi M, 2005). Ganongan merupakan pencerminan dari Pujangga Anom yang mempunyai fisik jelek, sekarang banyak beredar Ganongan dengan wajah seram dengan Taring yang menyerupai Raksana (Buto).

Program pemberdayaan masyarakat ini memfokuskan pada tranfers teknologi digital kepada mitra melalui system digital marketing untuk meningkatkan daya saing juga sebagai upaya mempertahankan (menjaga keaslianya) dan melestarikan (nguri-nguri=menghidup-hidupi) Reyog Ponorogo. Mitra dalam program ini adalah Rumah Seni Reog yang merupakan pengrajin perangkat Reyog Ponorogo yang konsiten pada pakem dan estetika, serta belum menggunakan teknologi dan system informasi dalam pemasarannya, Hal inilah yang mendasari pengabdi memilih rumah seni Reog sebagai mitra. Segmen pasar Rumah seni Reog adalah local, nasional, dan pasar internasional.

Permasalahan yang dihadapi oleh Rumah Seni Reog (Mitra) di antaranya: 1). Memasuki era revolusi industri 4.0 berbasis digitalisasi, mitra merasa kesulitan perluasan akses informasi dengan mengedepankan pakem dan estetika kesenian Reyog Ponorogo sebagai langkah antisipasi, pencitraan dan upaya menjaga eksistensi reyog Ponorogo di tingkat nasional maupun internasional, 2). Terintregrasinya hasil kerajian mitra dengan dinas terkait, penangkaran burung Merak, yayasan Reyog, dan pusat studi melalui system digital marketing kerajinan perangkat Reyog Ponorogo belum ada, dan 3) Proses manajerial yaitu: perencanaan, (planning), Pengorganisasian (organizing), pengarahan (leading), dan pengendalian (controlling), serta pembukuan, pelaporan, rekap penjualan dan order dilakukan secara manual, hal ini menghambat dan perkembangan usaha, sekaligus belum mampu bersaing. 
Tujuan kegiatan pengabdian kepada masyarakat skema PKM ini di antaranya: 1). Mendesain system digital marketing perangkat Reyog Ponorogo sebagai upaya mempertahanlan budaya adiluhung, 2) Implementasi system kepada mitra dan stake holder lainnya, dan 3) Meningkatkan literasi pengrajin Reyog Ponorogo dalam hal digital marketing.

Sasaran kegiatan PKM ini adalah pengrajin Reyog Ponorogo, yayasan Reyog Ponorogo, Masyarakat Ponorogo, dan stake holder reyog Ponorogo.

\section{METODE}

Diagram Prosedur kerja program pemberdayaan Mitra tahun 2020, sebagaimana Gambar 1., dan tahap Implementasi system sebagaimana Tabel 1.

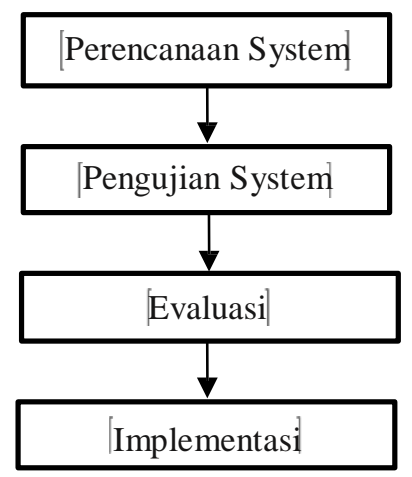

Gambar 1. Diagram Prosedur kerja program pemberdayaan masyarakat

\begin{tabular}{|c|c|}
\hline \multicolumn{2}{|r|}{ Tabel 1. Tahapan Penerapan Teknologi } \\
\hline Pihak & Aktifitas Tahapan Penerapan Teknologi \\
\hline Mitra & $\begin{array}{l}\text { 1. Pengumpulan data digital (foto \& video) } \\
\text { hasil produksi } \\
\text { 2. Input barang (harga, jumlah, jenis, type, } \\
\text { dan narasi) } \\
\text { 3. Pendampingan dari team dalam } \\
\text { pengoperasian system }\end{array}$ \\
\hline $\begin{array}{l}\text { Lab } \\
\text { Teknik }\end{array}$ & $\begin{array}{l}\text { 1. Koordinasi dengan Kepala laboratorium } \\
\text { 2. Proses desain system } \\
\text { 3. Pengujian system dan pembuatan } \\
\text { Topologi jaringan internet }\end{array}$ \\
\hline Team & $\begin{array}{l}\text { 1. Pembagian job description dan } \\
\text { Pemasangan peralatan bersama mitra } \\
\text { 2. Pendampingan di masing masing pihak } \\
\text { yang terlibat } \\
\text { 3. Pembuatan laporan di setiap kegiatan. }\end{array}$ \\
\hline
\end{tabular}

\section{Diskripsi Produk}

Desain system digital marketing, dan virtualisasi perangkat Reyog Ponorogo sebagaimana dalam Gambar 2.

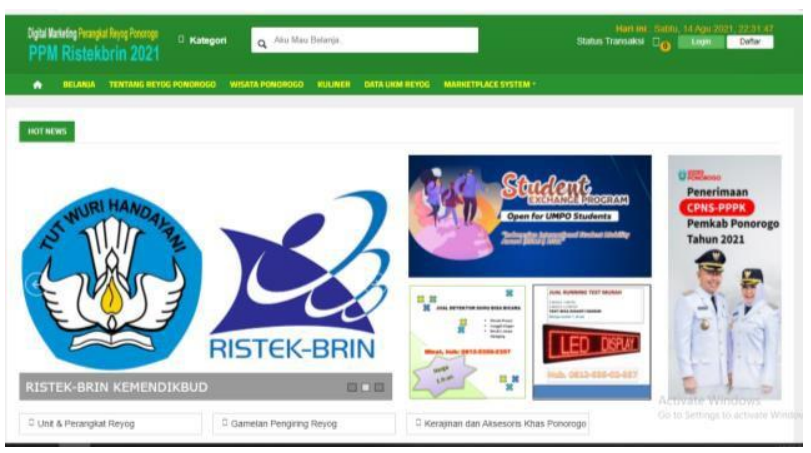

Gambar 2. Tampilan system digital marketing

\section{Prosedur kerja untuk mendukung realisasi metode yang ditawarkan}

Prosedur kerja tim pengabdi dalam mendukung realisasi metode di antaranya: a). studi pustaka, b) studi kasus penjualan di mitra, c) perencanaan data base perangkat kesenian Reyog Ponorogo, d) studi banding dengan dinas Pariwisata dan yayasan Reyog tentang desain perangkat yang sesuai pakem, e). menterjemahkan kesemua langkah kerja ke dalam system informasi. 


\section{Partisipasi Mitra dalam Pelaksanaan Program}

Mitra berpatisipasi dalam penyiapan dokumen hasil kerajinan, diskripsi barang, secara terbuka memberikan gambaran tentang peluang dan tantangan Reyog Ponorogo di masa yang akan datang, dan konsisten pada produk yang sesuai pakem.

\section{Evaluasi}

Evaluasi keberhasilan program dilakukan dengan membuat indicator-indikator capaian, yaitu: 1). Kemampuan mitra dalam memahami konten system digital marketing perangkat Reyog Ponorogo, 2). Aspek tingkat kemudahan dalam mengelola usaha dengan system, 3). Aspek kemampuan merespon transaksi yang ada di system

Keberlanjutan program dilakukan dengan pendampingan program, serta menjalin kerjasama dengan berbagai pihak untuk memanfaatkan system digital marketing ini sebagai sarana belanja secara online untuk kebutuhan perangkat Reyog Ponorogo dan kebutuhan lainnya yang menjadi produk unggulan kabupaten Ponorogo.

\section{HASIL DAN PEMBAHASAN}

Hasil PKM dapat dilihat dari indikator pencapaian tujuan pengabdian kepada masyarakat, dari aspek kemampuan mitra dalam memahami konten system digital marketing perangkat Reyog Ponorogo, dan mengimplemantasikan (input \& Output barang dagangan). Adanya peningkatan sebesar 15\%, hal ini menunjukkan bahwa mitra mengalami peningkatan dalam pengoprasionalan system digital marketing, dibuktikan dengan kemampuan mitra, berhasil mencoba menggunakan system yang di buat dengan tidak ada kendala.

Indikator pencapaian tujuan pengabdian kepada masyarakat, dari aspek tingkat kemudahan dalam mengelola usaha dengan system. Terjadi Peningkatan sebesar $75 \%$, artinya mitra sudah mencoba memasarkan dan memanfaatkan system sebagai salah satu sarana pemasaran, dengan mencoba menawarkan produknya melalui system yang sudah di desain.
Indikator pencapaian tujuan pengabdian kepada masyarakat, dari aspek kemampuan merespon transaksi yang ada di system. Peningkatan $100 \%$ hal ini dikarenakan sebelumnya belum pernah melakukan respon pembeli melalui system, ditandai dengan kemampuan merespon calon pembeli melalui system bisa dan sudah dilakukan dengan sukses.

Secara umum mitra sudah mencoba menggunakan system, walaupun transaksi masih 2 (dua) kali, karena kondisi saat ini penjualan perangkat Reyog Ponorogo mengalami penurunan yang drastis, bahkan banyak orderan yang di cancel/batal karena kondisi pandemic covid-19.

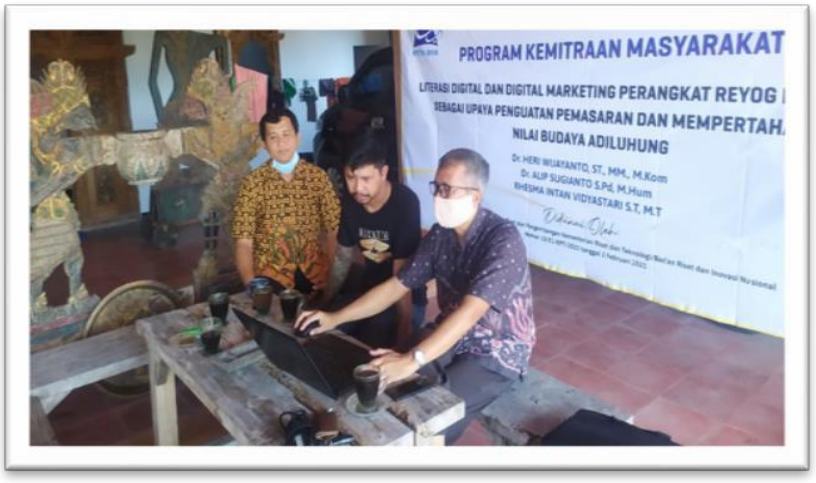

Gambar 3. Pelatihan penggunaan system pada Mitra
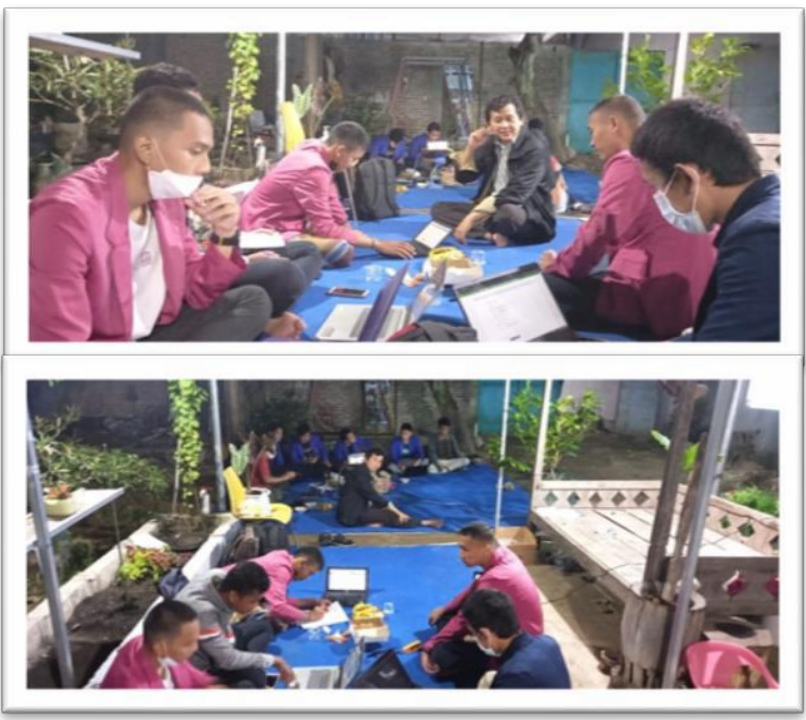

Gambar 4. Pelatihan penggunaan system pada Siswa dan masyarakat 


\section{KESIMPULAN}

Kesimpulan yang dapat diperoleh, dengan kegiatan pengabdian kepada masyarakat ini adalah:

1. Literasi digital mitra mengalami peningkatan dengan adanya system digital marketing perangkat reyog Ponorogo, hal ini menunjukkan bahwa system yang dibangun memberikan manfaat dalam memasarkan perangkat reyog Ponorogo.

2. Sistem digital marketing yang sudah selesai di desain dan di implemantasikan sedikit membantu memasarkan produksi, walaupun belum ada transaksi, karena belum ada yang beli perangkat reyog Ponorogo di masa Pandemi Covid-19.

3. System digital marketing yang didesain sudah bisa digunakan untuk bertransaksi secara online melalui web. https://ukmreyog.solusi17.com.

\section{UCAPAN TERIMAKASIH}

Ucapan terimakasih disampaikan kepada: 1). Kementerian riset dan teknologi/badan riset dan inovasi nasional, deputi bidang penguatan riset dan pengembangan yang telah mendanai program pengabdian ini, 2) LPPM Universitas Muhammadiyah Ponorogo yang memberikan dukungan terhadap pelaksanaan program, 3) fakultas Ekonomi dan falultas Teknik Universitas Muhammadiyah Ponorogo yang telah membantu pelaksanaan program.

\section{REFERENSI}

Badan Pusat Statistik Kabupaten Ponorogo, 2006/2007, "Kabupaten Ponorogo dalam Angka"

Jusuf Harsono, Wijayanto Heri, 2009, ”Penyusunan Pedoman pembuatan perangkat kesenian Reyog Ponorogo sebagai upaya mempertahankan dan melestarikan budaya adiluhung", Laporan Penelitian Lembaga Penelitian dan Pengabdian pada Masyarakat Universitas Muhammadiyah Ponorogo.

Kurnianto, Rido, dkk., 2006. "Tradisi Warok dan Marginalisasi Perempuan di Kabupaten Ponorogo", Hasil penelitian yang didanai Dirjen Dikti Diknas Jakarta tahun 2006, LPPM Unmuh Ponorogo.

Nursilah, 2001, "Reyog Ponorogo Kajian Terhadap Seni Pertunjukan Rakyat Sebagai Pembentuk Identitas Budaya", FISIP UI, Jakarta.

Purwowijoyo, 1971, "Babad Ponorogo Jilid I", Wredatama kantor pembinaan pendidikan masyarakat Ponorogo, Bandung.

Wijayanto Heri, Pramono, 2007, 'Pengingkatan pengetahuan dan ketrampilan melalui magang kewirausahaan pada Pengrajin Reyog Ponorogo", Lembaga Penelitian dan Pengabdian pada Masyarakat Universitas Muhammadiyah Ponorogo.

Zamzam Fauzannafi M, 2005, "Reog Ponorogo menari di antara dominasi dan keragaman”, Kepel Press, Yogyakarta. 